
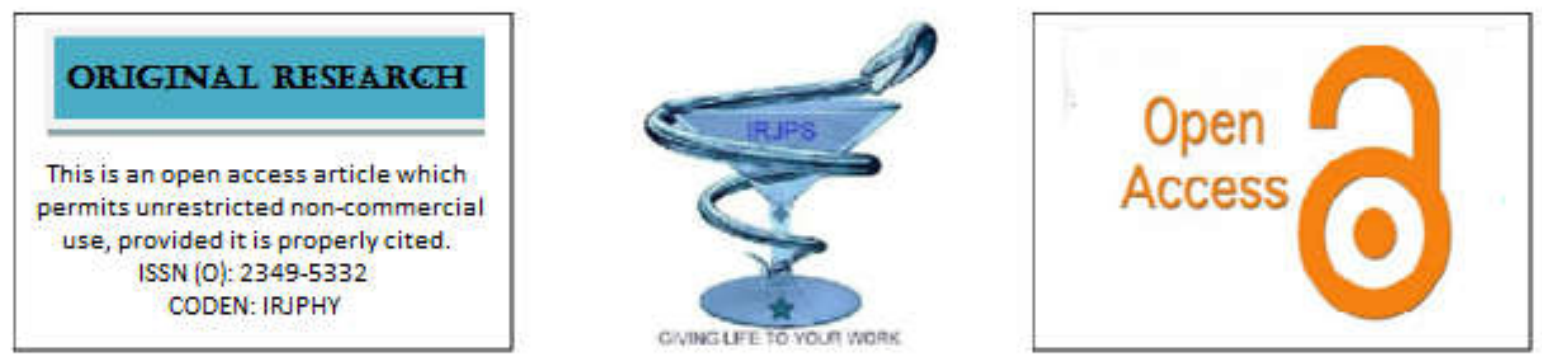

\title{
FORMULATION AND EVALUATION OF TRANSDERMAL DRUG DELIVERY OF VITAMIN A THE TREATMENT OF MUMPS
}

\author{
Varsha Lodhi*, Dr. Sarika Shrivastava, Dr. Kavita R Loksh, Dr. Abhishek Singh Kushwaha \\ Oriental Collage of Pharmacy, Raisen Road, Patel Nagar, Bhopal - 462021
}

Submitted on: 28.11.2020;

Revised on: 05.12.2020;

Accepted on: 17.12.2020

\begin{abstract}
The purpose of this research was to develop a drug -in- adhesive type transdermal drug delivery system containing drug retinol for treatment of mumps disease, pressure sensitive adhesive (PBS). Duro-Take 3872516 by the solvent evaporation method different penetration enhancers- Laureth-4, Lauryl lactate, Levulinic acid, Isopropyl myristate, Dimethyl sulfoxide, Oleic acid used as permeation enhancers. Were used to enhance the transdermal permeation of retinol drug delivery. 3M scotchpak TM 9723 polyester film was used as a backing membrane scotchpak TM 1022 fluropolymer coated polyester film was used as a release liner for the prepared drug in adhesive transdermal patches were physically evaluated with regrade to folding endurance, thickness, weight variation, moisture loss and moisture absorption. In vitro drug permeation studies of formulation was performed by using Franz diffusion cell through human cadaver skin, The Invitro release studies of formulation was performed by using Franz diffusion cell through Polyether sulfone (PES) The adhesion properties of the patches were very satisfactory. All prepared formulation indicated good physical stability.
\end{abstract}

KEYWORDS: Drug-in-adhesive, In vitro permeation study, In vitro release study, Permeation enhancers, Transdermal patch

Corresponding author: Varsha Lodhi
Email id: varshathakur920@gmail.com
Indian Research Journal of Pharmacy and Science; 26(2020)2439-2452; Journal Home Page: https://www.irjps.in DOI: $10.21276 /$ irjps.2020.7.4.5 
INTRODUCTION: Mumps also called epidermicparotitis, acute contagious disease caused by a virus and characterized by inflammation swelling of the salivary gland. It frequently occurs as an epidemic and most commonly affects young persons who are between 5 and 15 years of age. ${ }^{1}$ The mumps caused by the RNA virus, Rubulavirus. Rubulavirus is within the genus Paramyxovirus and is a member of the family Paramyxoviridae. The mumps virus (MuV) genome is a non-segmented single-stranded negative strand RNA that contains 15,384 nucleotides. ${ }^{2}$ It encodes seven tandemly linked transcription units. Complications of Mumps orchitis, epididymitis, bilateral orchitis, subfertility, testicular atrophy, oophoritis, meningitis, pancreatitis, spontaneous abortion ${ }^{3}$. There is no current treatment for mumps other than pain killer or supportive care. Vaccination in developed countries have markedly reduce in the risk of mumps infection. Retinol delivery through the transdermal route Transdermal drug delivery provides a constant rate of release of medicine to maintain concentration level of drug for a longer period as to avoid peak and valley associated with oral dosing and parenteral administration. Retinoidsinhibit $\mathrm{MuV}$ in vitro due to up-regulation of type I interferon (IFN) and IFN stimulated genes. This effect is mediated by nuclear retinoid receptor signaling and RIG-I is required. The antiviral retinoid-induced state makes cells less permissive to viral replication from subsequent challenge with either $\mathrm{MuV}$ or $\mathrm{MeV}$ for less than 12 hours. $^{4}$

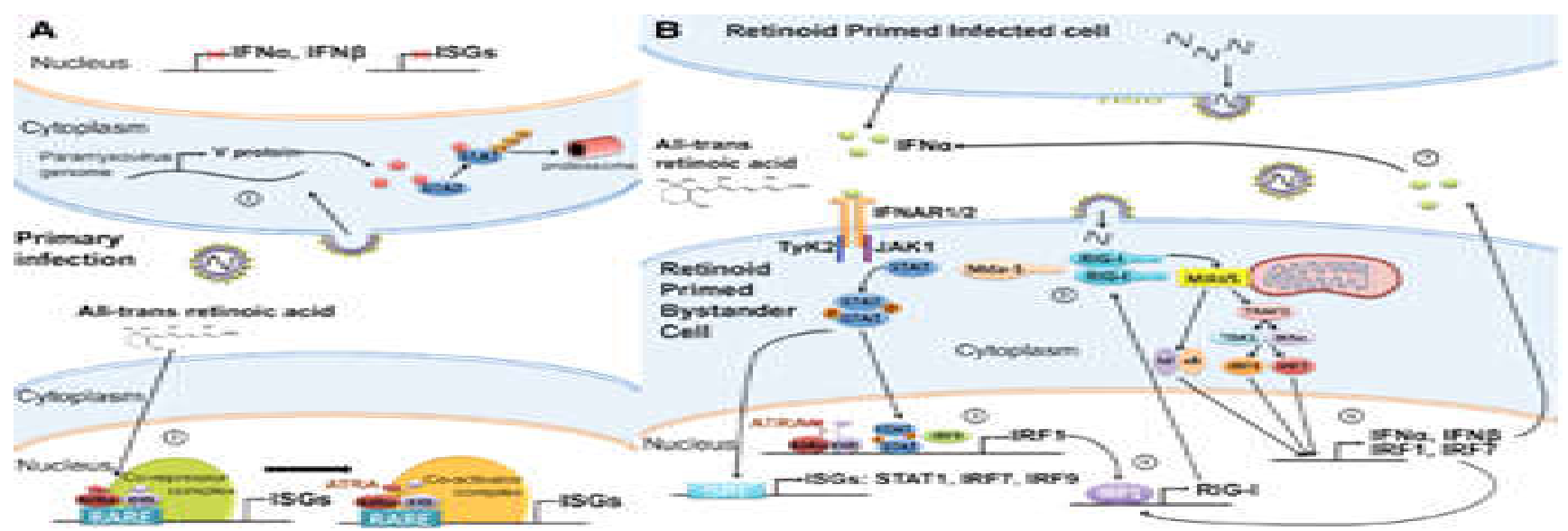

Figure1: Retinoid action during paramyxovirus infection

\section{MATERIALS AND METHOD}

Retinol was purchased from Sigma Aldrich Mumbai, Durotake 387-2516 gift sample from Henkel Ltd., Isopropyl myristate sample from BASF Ltd. Mumbai, and Laureth-4, Lauryl lactate, Lavulinic acid, Oleic acid, Propylene glycol sample of croda Mumbai, Synthetic membrane Polyether sulfone (PES) purchased Axiva Sichem Pvt. Ltd.

\section{METHOD}

\section{PREFORMULATION STUDIES}

The pre-formulation study was performed to assure the authenticity of sample drug and determination of some parameters for development of Transdermal formulation. Preformulation studies of Retinol including identification of drug, determination of melting point, determination of partition co-efficient and identification of drug sample by FT-IR spectroscopy and results was compared with the references. 


\section{Physical appearance}

The drug (retinol) was obtained as a Sigma Aldrich. The supplied sample of retinol was pale yellow powder.

\section{Determination of melting point}

Melting point of retinol (vitamin A) was performed by using capillary tube method. A powder of retinol was filled in the capillary tube, this tube previously sealed at one end side and the capillary tube was tied to the bottom of the thermometer. The thermometer and capillary tube were immersed into the liquid paraffin taken in the tube. Bottom of the tube was heated by means of burner. When the sample start to melt, and reading was recorded.

\section{Solubility studies}

The sample of drug was quantitively tested for its solubility in various solvent. It was determined by shaking $1 \mathrm{mg}$ drug sample in $2 \mathrm{ml}$ of solvent (i.e., Water, PBS (pH 7.4), Ethanol, Acetone, Mineral oil, DMSO, DUROTAKE 387-2516).

\section{Determination of partition co-efficient ${ }^{5}$}

The two phases (water and n-octanol) were mixed in equal quantities and kept for saturation in separating funnel. The partition coefficient was determined by taking $5 \mathrm{mg}$ of the drug into the solution and shaking them occasionally and the resulting the two phases were carefully separated in a separating funnel. The organic phase was filtered through Whatman filter paper, suitably diluted, and the amount of retinol in the organic phase was determined by measuring absorbance at $325 \mathrm{~nm}$ using HPLC. The partition coefficient of the drug was calculated by using the following formula: -

$$
\mathrm{K} \mathrm{o} / \mathrm{w}=\frac{\text { Amount of drug in organic layer }}{----------------}
$$

\section{Fourier-transform infrared spectroscopy}

The infrared spectroscopy of the pure drug was carried out to identity the drug. A powder of drug was prepared by compressing of the drug with IR grade $\mathrm{KBr}$ by applying pressure in $\mathrm{KBr}$ press. The drug sample was mounted in IR compartment and scanned between wave numbers 3338 to $410 \mathrm{~cm}^{-1}$ using a FTIR spectrophotometer (Bruker Alpha-I).
Preparation of calibration curve

Retinol has been quantitatively analyzed by various techniques. In the present study, retinol was estimated by high performance liquid chromatography method.

\section{Preparation of primary stock solution}

About $5 \mathrm{mg}$ of retinol was weighed and dissolved in about $5 \mathrm{ml}$ of dimethyl sulfoxide. The volume to get a primary stock solution of $1 \mathrm{mg} / \mathrm{ml}$.

\section{Preparation of working standard solution}

Working standard solutions having concentrations 1.25 to $0.078 \mathrm{mg} / \mathrm{ml}$ was prepared by suitably diluting the primary stock with dimethyl sulfoxide, respectively. The absorbance of the each working standard solution was measured and a graph of concentration of the solution was plotted against absorbance in Microsoft Excel software.

\section{PREPARATION OF TRANSDERMAL PATCH 6,7}

\section{Preparation of drug loaded transdermal Patch}

Transdermal patches were prepared by solvent evaporation method. Specific amount of DUROTAKE 387-2516 and Retinol was taken in the glass vial. A homogeneous drug and pressure sensitive adhesive solution was made using a Vortex Mixer at room temperature and vial covered with vial cap for preventing solvent evaporation process. After that required permeation enhancers was added and checked the $\mathrm{pH}$ of homogeneous mixture \& stirred until a homogeneous mixture was kept in sonicator for elimination of air bubbles. The require amount of ingredients mentions in the table 1 .

\section{Casting of polymeric solution over the Backing membrane}

The backing membrane was held in place on a chopping board, a sample of each polymeric adhesive mixture $(2 \mathrm{ml})$ was placed across the top edge of the backing membrane, the mixture was casted onto the backing liner by drawing a multiple clearance film applicator. The wet adhesive film was dried at $50^{\circ} \mathrm{C}$ for 20 minutes. After that Release linear was placed on the top of the coatings. The film was laminated on to a release linear using a film was cut into $5 \mathrm{~cm}^{2}$, stored in double sealed Ziplock bag. 
Table1: Formulation chat of Retinol Transdermal Patch

\begin{tabular}{|l|c|c|c|c|}
\hline \multicolumn{1}{|c|}{ Ingredient } & $\begin{array}{c}\text { F 1 } \\
\text { wt/wt \% }\end{array}$ & $\begin{array}{c}\text { F2 } \\
\text { wt/wt \% }\end{array}$ & $\begin{array}{c}\text { F3 } \\
\text { wt/wt \% }\end{array}$ & $\begin{array}{c}\text { F4 } \\
\text { wt/wt \% }\end{array}$ \\
\hline Retinol & $\mathbf{2}$ & $\mathbf{2}$ & $\mathbf{2}$ & $\mathbf{2}$ \\
\hline Duro-take387-2516 & $\mathbf{8 3}$ & $\mathbf{8 5}$ & $\mathbf{8 3}$ & $\mathbf{8 3}$ \\
\hline Propylene glycol & $\mathbf{5}$ & $\mathbf{5}$ & $\mathbf{5}$ & \\
\hline Laureth-4 & $\mathbf{5}$ & $\mathbf{5}$ & & \\
\hline Lauryl Lactate & $\mathbf{5}$ & & & \\
\hline Levulinic acid & & $\mathbf{3}$ & $\mathbf{3}$ & \\
\hline Isopropyl myristate & & & & \\
\hline DMSO & & & $\mathbf{7}$ & $\mathbf{5}$ \\
\hline Oleic acid & & & & $\mathbf{5}$ \\
\hline Total & $\mathbf{1 B}$ & $\mathbf{1 0 0}$ & $\mathbf{1 0 0}$ & $\mathbf{1 0 0}$ \\
\hline
\end{tabular}

\section{EVALUATION OF PREPARE TRANSDERMAL PATCH}

The prepare transdermal patch were evaluated for its Organoleptic Characteristics Thickness of patch, Drug content uniformity test, Uniformity of weight, Folding Endurance, In vitro release rate (IVRT) study, In vitro permeation release (IVPT) study.

\section{Organoleptic Characteristics}

The prepared patch was physically inspected for its appearance, colour, clarity, flexibility, and smoothness.

\section{Thickness of patch ${ }^{8,9}$}

The thickness of the backing membranes (before casting the drug matrix) and whole patches (adhesive matrix with the drug plus the backing membrane) was measured at three different point of each formulated patches into ensure uniform thickness using thickness gauge. The average thickness of the backing membrane of drug matrix with the backing membrane of drug matrix with the backing membrane was determined. The thickness of the drug containing polymer matrix was determined by measuring the thickness of the whole patch and minus the thickness of the backing membrane. The average thickness of the drug containing polymer matrix was determine: - Thickness of the drug containing adhesive matrix $=$ Thickness of the whole patch - Thickness of the backing membrane.

\section{Weight Uniformity ${ }^{10}$}

A specified area of patch is to be cut in different parts of the patch using a hollow punch and weigh in digital balance. The average weight and standard deviation values are to be calculated from the individual weights.

\section{Drug Content Uniformity ${ }^{11,12}$}

An accurately cut patch of $1 \mathrm{~cm}^{2}$ area was taken and added to a glass vial containing $2 \mathrm{ml}$ Dimethyl sulfoxide. The glass vial was shaken for 24 hours in a Rotary Mixer. Then the solution was filtered and the analyzed drug content using HPLC method.

\section{Folding Endurance ${ }^{13}$}

The prepared transdermal patch folding endurance was measured by manually. A strip of patch was cut and repeatedly folded at the same place until a visible broke / crack. The number of times the patch folded at the same place without breaking/ cracking and the value was reported.

\section{Percentage of Moisture Loss ${ }^{14,15}$}

The films of all the batches was selected. The films were weighed accurately and place in a desiccator containing fused calcium chloride at room temperature for $24 \mathrm{~h}$. After $24 \mathrm{~h}$, the films are to be reweighed to determine the percentage moisture content from the below-mentioned formula:

$$
\begin{gathered}
\text { Initial Weight }- \text { Final Weight } \\
\% \text { of moisture loss }= \\
\text { Initial Weight }
\end{gathered}
$$




\section{Percentage of Moisture Absorption ${ }^{15}$}

The films of all the batches was selected. The films were weighed accurately and are to be kept in a desiccator at room temperature for $24 \mathrm{~h}$, which contains a saturated solution of potassium chloride to maintain $84 \% \mathrm{RH}$. After $24 \mathrm{~h}$, the films are to be reweighed to determine the percentage moisture uptake from the below-mentioned formula:
$\%$ of moisture loss =

Final Weight - Initial Weight

Initial Weight

\section{In Vitro Permeation Test (IVPT) Study}

In vitro drug release profiles were carried out by using Franz diffusion cell with human cadaver skin. Human cadaver skin was obtained from the thigh area of male donor. The Franz diffusion cell consists of two compartment, first donor compartment and second receptor compartment. The donor compartment was in contact with ambient conditions of the atmosphere. [8,9] And cell active diffusion area $0.6 \mathrm{~cm}^{2}$ the receptor compartment was in contact with a solution in the receptor compartment (phosphate buffer saline $+0.01 \%$ Sodium Azide and $2 \%$ hydroxypropyl beta cyclodextrin).

\section{Cell Assembly}

Place the cells on the dry bath stirrer. And place the stirring bars in cells, the fill $4.8 \mathrm{ml}$ of the receptor fluid in the cells. Set the temperature at $32^{\circ} \mathrm{C}$ and speed at $400 \mathrm{rpm}$. Mount the skin on the active diffusion area. Place the donor part on it and carefully clamp both the parts using pinch clamp. Check the impedance of each cell using LCR meter.

\section{Dosing}

The patch is cut into a desired size (according to the size of active diffusion area of Franz diffusion cell) and removed the upper layer of the patch, apply the patch on the skin.

\section{Sampling}

For sampling, the time points are decided before conducting the test. The time points can be like 0,1 , 2, 3, 4, 6 hours. The samples collected are $300 \mu 1$. After the sampling, the cells are refilled. The samples are to be stored in the refrigerator.

\section{Post Flux Studies}

The cells are then disassembled, and the skin is separated for the dermis and epidermis separation with the help of spatula. The dermis and epidermis are placed in different vials for each replicate. Add 3 $\mathrm{ml}$ of DMSO solvents in the vials. After that $24 \mathrm{hr}$ all extraction sample shake with the help of shaker at room temperature. The samples are analyzed with help of HPLC method.

\section{Table:2 General Information in IVPT study}

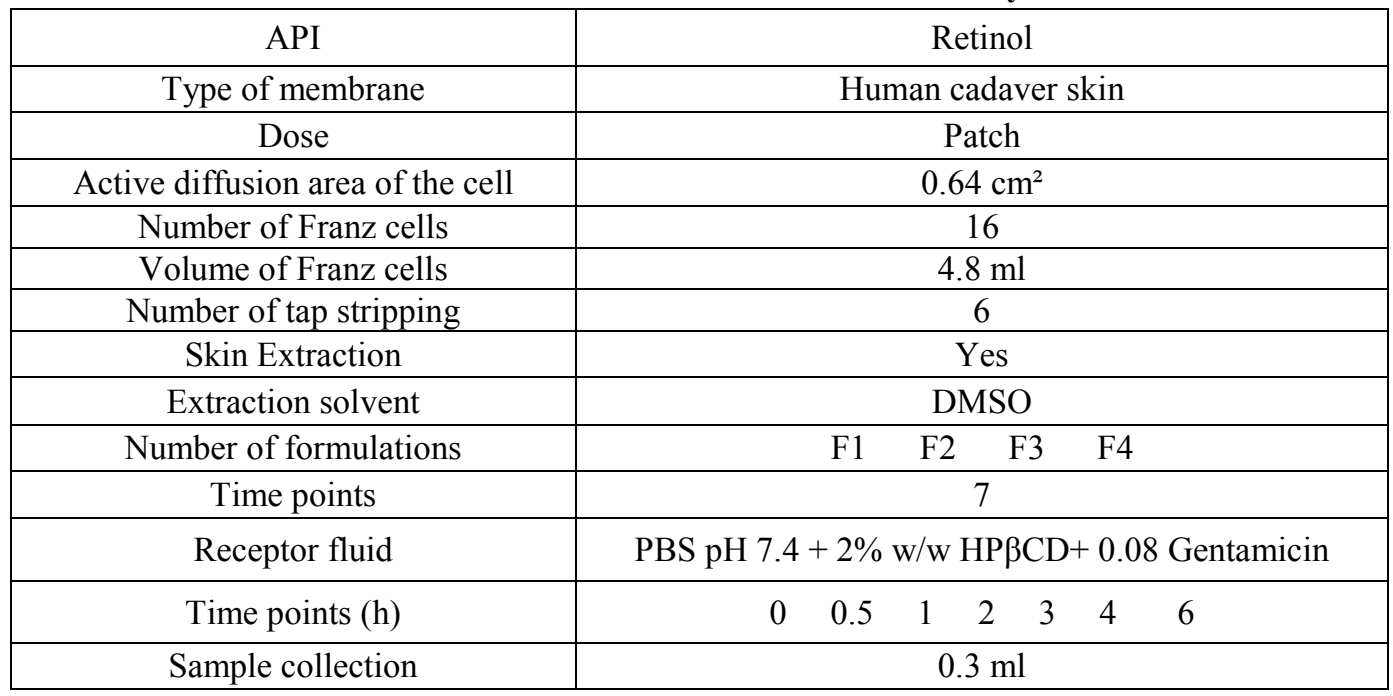


In Vitro Release Rate (IVRT) Study

In vitro drug release profiles were carried out by using Franz diffusion cell with Polyether sulfone (PES) membrane (synthetic membrane). The Franz diffusion cell consists of two compartment, first donor compartment and second receptor compartment. The donor compartment was in contact with ambient conditions of the atmosphere. And cell active diffusion area $0.6 \mathrm{~cm}^{2}$ the receptor compartment was in contact with a solution in the receptor compartment ( $70 \%$ ethanol). ${ }^{8,9}$

Table:3 General Information in IVRT study

\begin{tabular}{|c|c|}
\hline API & Retinol \\
\hline Type of membrane & Polyether sulfone \\
\hline Dose & Patch $(0.8 \mathrm{~mm})$ \\
\hline Active diffusion area of the cell & $0.64 \mathrm{~cm}^{2}$ \\
\hline Number of Franz cells & 6 \\
\hline Volume of Franz cells & $4.8 \mathrm{ml}$ \\
\hline Number of formulations & F1 \& F2 \\
\hline Time points & 7 \\
\hline Receptor fluid & $70 \%$ Ethanol \\
\hline Time points (h) & $0,0.5,1,2,3,4,6$ \\
\hline Sample collection & $300 \mu 1$ \\
\hline
\end{tabular}

\section{RESULT}

Pre-formulation studies

Physical character

Table 4: Physical character of pure drug (Retinol)

\begin{tabular}{|c|c|c|}
\hline S.no. & Physical Characteristic & Result \\
\hline $\mathbf{1}$ & Colour & Yellowish \\
\hline $\mathbf{2}$ & Odour & Odour Less \\
\hline $\mathbf{3}$ & Appearance & Yellowish powder \\
\hline
\end{tabular}

Determination of Solubility, Melting Point and Determination of Partition Coefficient.

Table 5: Solubility, Melting Point and Partition Coefficient

\begin{tabular}{|c|c|c|}
\hline Sno & Parameter & Res:l's \\
\hline $\mathbf{1}$ & Solythy & 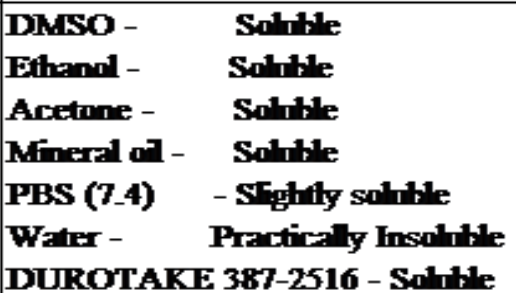 \\
\hline 2 & Meling Point & \begin{tabular}{|c|} 
62R \\
\end{tabular} \\
\hline 3 & Partition Coefficient & 435 \\
\hline
\end{tabular}


Fourier-transform infrared spectroscopy (FT-IR):

Sample of pure Retinol the FTIR spectrum of sample drug shows the peak values which are characteristics of the drug and the graph were shown in Figure 2.

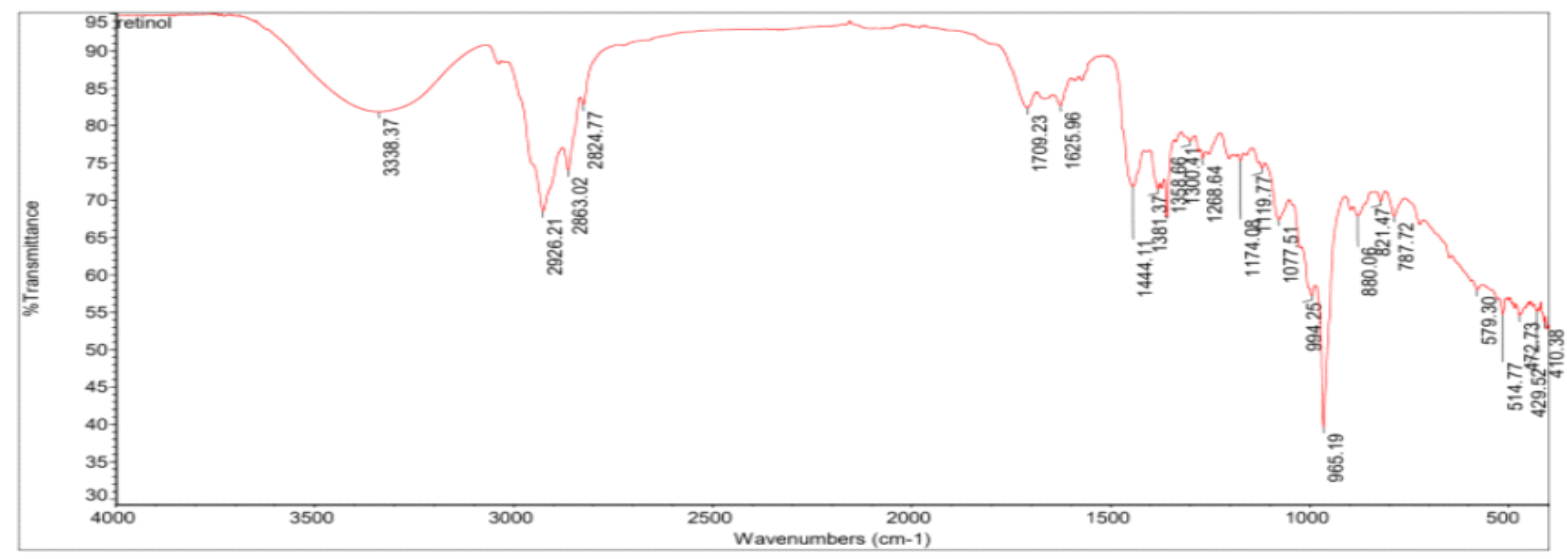

Figure 2: FTIR spectra data of retinol

\section{Development of Calibration Curve for Retinol}

The absorption maximum ( $\chi$ max) was determined as $325 \mathrm{~nm}$. The concentration ranges and data are reported in table 6 . And calibration curve of retinol was plotted using this data and shown in figure 3.

Table 6: Calibration data for retinol in DMSO

\begin{tabular}{|l|c|c|c|}
\hline \multicolumn{4}{|c|}{ Calibration Curve in DMSO } \\
\hline Drug name & Retinol & Con.(ug/ml) & Area \\
\hline Standard Solvent & DMSO & 1.25 & 117315 \\
\hline Receptor fluid & Ethanol & 0.625 & 58757 \\
\hline & & 0.312 & 28202 \\
\hline Slope & 93661 & 0.156 & 14970 \\
\hline Intercept & 92.5 & 0.078 & 7973 \\
\hline Concentration & \multirow{2}{*}{$1 \mathrm{mg} / \mathrm{ml}$} & & \\
\hline
\end{tabular}

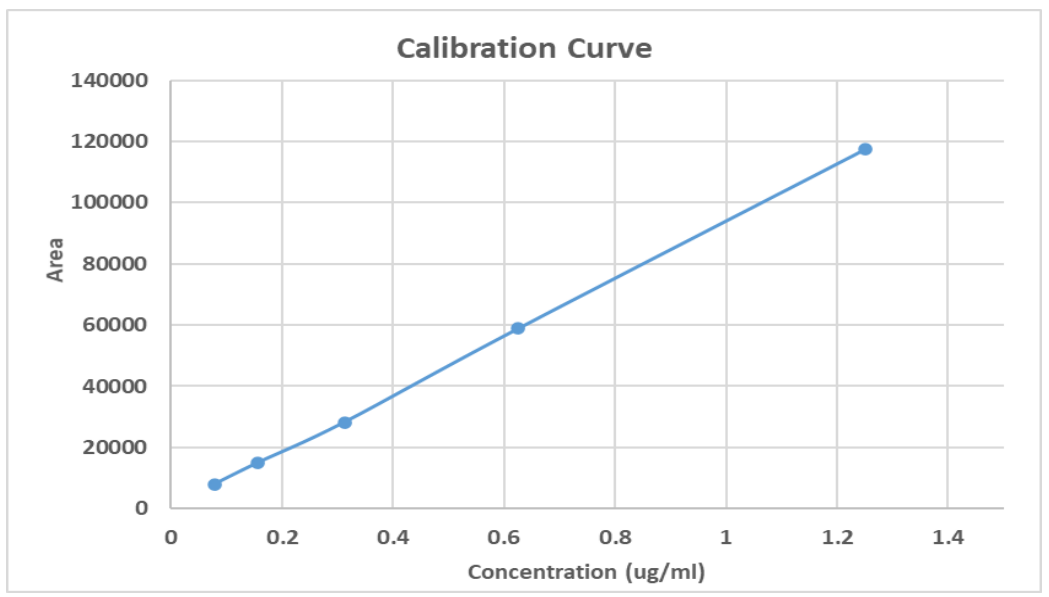

Figure3: Calibration Curve of Retinol 
EVALUTION OF THE FORMULATED

TRANSDERMAL PATCH

Transdermal patch was prepare using solvent evaporation method.
Organoleptic characteristics

Prepared patch was colour, clarity, flexibility, and smoothness given in table 7 .

Table 7: Organoleptic characteristics of the prepared patches.

\begin{tabular}{|c|c|c|}
\hline S.no. & Physical Characteristic & Result \\
\hline 1 & Colour & Yellow \\
\hline 2 & Clarity & Transparent \\
\hline 3 & Flexibility & Flexible (Good) \\
\hline 4 & Smoothness & Smooth (Good) \\
\hline
\end{tabular}

Thickness of patch:

The mean thickness of prepared patches were $0.23 \pm 0.005$ to $0.27 \pm 0.005 \mathrm{~mm}$ as given in Table 8

Table 8: Thickness of Retinol patch (whole patch thickness)

\begin{tabular}{|c|c|c|c|c|c|}
\hline \multirow{2}{*}{ S.Ne. } & \multirow{2}{*}{$\begin{array}{c}\text { Fermalntien } \\
\text { Code }\end{array}$} & \multicolumn{3}{|c|}{ Thirkness ef patth in mo } & \multirow{2}{*}{$\operatorname{Men} \pm S . D^{*}$} \\
\hline & & Trial I & Trinl II & Trivil III & \\
\hline $\mathbf{1}$ & F1 & 0.18 & 0.17 & 0.18 & $0.17 \pm 0.005$ \\
\hline 2 & $\mathbf{F} 2$ & 0.19 & 0.17 & 0.17 & $0.17 \pm 0.011$ \\
\hline 3 & $\mathbf{F} 3$ & 0.17 & 0.16 & 0.17 & $0.16 \pm 0.015$ \\
\hline 4 & F4 & 021 & 02 & 021 & $0.20 \pm 0.051$ \\
\hline
\end{tabular}

Table 9: Thickness of Retinol patch adhesive matrix with the drug plus backing membrane.

\begin{tabular}{|c|c|c|c|c|c|}
\hline \multirow{2}{*}{ S.Ne. } & \multirow{2}{*}{ Formuntien } & \multicolumn{3}{|c|}{ Thirkness ef patch i m mo } & \multirow{2}{*}{$\operatorname{Men} \pm \mathbf{S} . D^{*}$} \\
\hline & & Trinl I & Trill II & TrinlII & \\
\hline $\mathbf{I}$ & F1 & 025 & 024 & 025 & $024 \pm 0.015$ \\
\hline 2 & $\mathbf{F} 2$ & 026 & 0.24 & 0.24 & $024 \pm 0.011$ \\
\hline 3 & F3 & 024 & 023 & 024 & $023 \pm 0.015$ \\
\hline 4 & $\mathbf{F 4}$ & 0.28 & 027 & 028 & $027 \pm 0.015$ \\
\hline
\end{tabular}

*Standard deviation, $n=3$

Uniformity weight: The weights range between

$21.10 \pm 0.2$ to $21.50 \pm 0.2$ and all the formulation weight show in Table 10. 
Table 10: Uniformity weight of Retinol patches

\begin{tabular}{|c|c|c|c|c|c|}
\hline \multirow{2}{*}{ S. Ne } & \multirow{2}{*}{ Fermelntine } & \multicolumn{3}{|c|}{ Thirkmess ef pated in men } & \multirow{2}{*}{ Meñ \pm S. } \\
\hline & & Trinl I & Trïl II & Trinl III & \\
\hline $\mathbf{1}$ & F1 & 215 & 209 & 212 & $2120 \pm 03$ \\
\hline 2 & $\mathbf{F 2}$ & 21.4 & 21.4 & 215 & $21.43 \pm 0.05$ \\
\hline 3 & $\mathbf{P 3}$ & 21.1 & 209 & 213 & $2110 \pm 02$ \\
\hline 4 & $\mathbf{F 4}$ & 21.7 & 215 & 213 & $2150 \pm 02$ \\
\hline
\end{tabular}

*Standard deviation, $n=3$

Drug content:

The drug content of the prepared patches were 1.90 to $3.54 \mathrm{ug} / \mathrm{ml}$ show drug content of patch as given in Table 11.

Table 11: Drug content of $0.8 \mathrm{~cm}^{2}$ Retinol patch.

\begin{tabular}{|c|c|c|}
\hline Sno. & Formulation code & 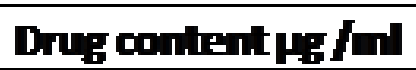 \\
\hline 1 & $\mathbf{F 1}$ & 3.01 \\
\hline 2 & F2 & 3.2 \\
\hline 3 & F3 & 3_54 \\
\hline 4 & F4 & 1.9 \\
\hline
\end{tabular}

Folding endurance:

The mean folding endurance of prepared patches were $250.00 \pm 1$ to $256.44 \pm 9.29$ all the formulations folding endurance in Table 12.

Table 12: Folding endurance of Retinol patches.

\begin{tabular}{|c|c|c|c|c|c|}
\hline \multirow{2}{*}{ S. Ne. } & \multirow{2}{*}{ Formulation } & \multicolumn{3}{|c|}{ Folding endwrince } & \multirow{2}{*}{$\operatorname{Mea} \pm$ S.D } \\
\hline & & Trivl I & Trial II & Trivl III & \\
\hline $\mathbf{1}$ & F1 & 250 & 267 & 252 & $256.44 \pm 929$ \\
\hline 2 & $\mathbf{F} 2$ & 252 & 257 & 255 & $254.67 \pm 251$ \\
\hline 3 & F3 & 249 & 250 & 251 & $250.00 \pm 1.00$ \\
\hline 4 & F4 & 253 & 253 & 255 & $253 \_66 \pm 1.15$ \\
\hline
\end{tabular}

*Standard deviation, $n=3$

Percentage of Moisture Loss

The percentage moisture content of all the patches were determine and was found in range of $1.29 \pm$
0.17 to $3.04 \pm 0.6$ and all formulation $\%$ moisture loss data show in table 13 . 
Table 13: Data of percentage of moisture loss of $1 \mathrm{~cm}^{2}$ Retinol patch

\begin{tabular}{|c|c|c|c|c|c|}
\hline \multirow{2}{*}{ S. Ne } & \multirow{2}{*}{$\begin{array}{c}\text { Fermalinen } \\
\text { Cede }\end{array}$} & \multicolumn{3}{|c|}{ * ef Mnistime Less } & \multirow{2}{*}{ Mean \pm S.W" } \\
\hline & & Trinl I & TrîlII & Tri-l III & \\
\hline $\mathbf{1}$ & FI & 253 & 288 & $2 \_14$ & $251 \pm 035$ \\
\hline 2 & $\mathbf{F 2}$ & 211 & 226 & 2.08 & $2 \_15 \pm 0.09$ \\
\hline 3 & $\mathbf{F 3}$ & 1119 & 1 1.48 & 1 18 & $129 \pm 0.17$ \\
\hline 4 & $\mathbf{F 4}$ & 32 & 35 & 23 & $3.04 \pm 0.6$ \\
\hline
\end{tabular}

*Standard deviation, $\mathbf{n}=\mathbf{3}$

Percentage of Moisture Absorption

The percentage moisture absorption of all the patches were determine and was found in range of $1.29 \pm$
0.17 to $3.04 \pm 0.6$ and all formulation percentage moisture absorption data show in table 14 .

Table 14: Data of percentage of moisture absorption of $1 \mathbf{c m}^{2}$ Retinol patch

\begin{tabular}{|c|c|c|c|c|c|}
\hline \multirow{2}{*}{ S. Ne. } & \multirow{2}{*}{ Formulatien } & \multicolumn{3}{|c|}{ * of Moisture absorption } & \multirow{2}{*}{$\operatorname{Me}= \pm$ S.D" } \\
\hline & & Trivl I & Trial II & Trivl III & \\
\hline $\mathbf{I}$ & FI & 3.84 & 336 & 3.65 & $3.62 \pm 0.24$ \\
\hline $\mathbf{2}$ & $\mathbf{F}$ & 328 & 3.19 & 321 & $3.22 \pm 0.04$ \\
\hline 3 & $\mathbf{F 3}$ & 297 & 2.67 & 2.88 & $2.84 \pm 0.15$ \\
\hline 4 & $\mathbf{F} 4$ & 4.13 & 421 & 4.1 & 4_14 \pm 0.05 \\
\hline
\end{tabular}

*Standard deviation, $\mathbf{n}=\mathbf{3}$

In Vitro Permeation Test (IVPT):

In vitro permeation study was carried out in Franz

Diffusion Cell using human cadaver skin

.Table 15: The amount of drug retained in the epidermis $(\mu \mathrm{g} / \mathrm{ml})$

\begin{tabular}{|c|c|c|}
\hline S. Ne. & Permatien code & Dreg retrined in Ppideris (ngran \\
\hline $\mathbf{1}$ & F1 & 3.01 \\
\hline 2 & $\mathbf{F 2}$ & 32 \\
\hline 3 & F3 & 354 \\
\hline 4 & F4 & 19 \\
\hline
\end{tabular}




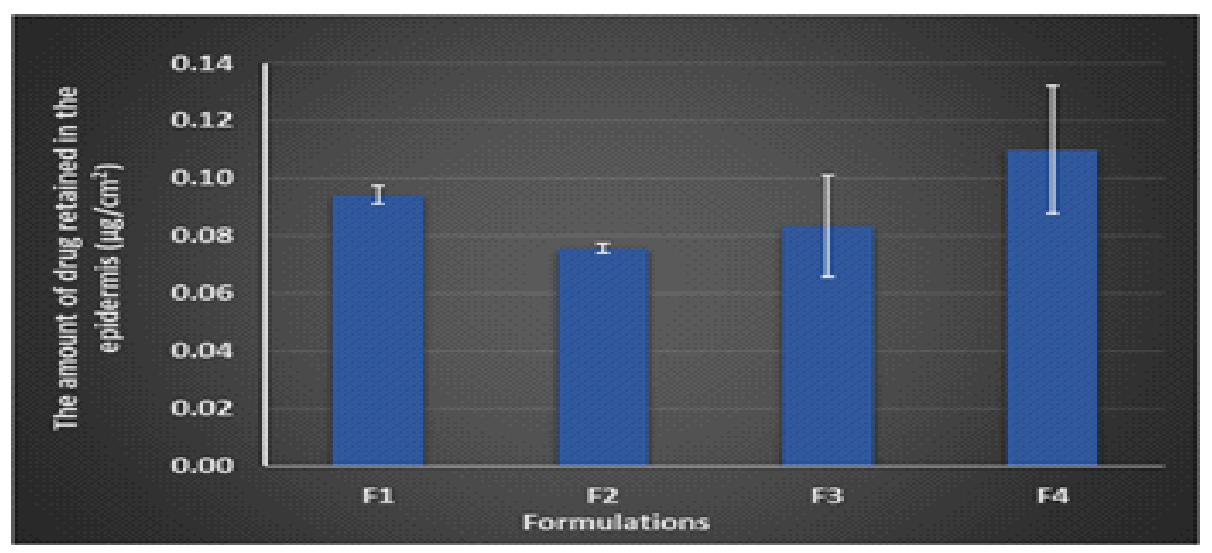

FIGURE 4: Shows the amount of retinol extracted from the active diffusion area of the epidermis layer. The drug amount was represented in $\mu \mathrm{g} / \mathrm{cm}$ unit.

Table 16: The amount of drug retained in the dermis $\left(\mu \mathrm{g} / \mathrm{cm}^{2}\right)$

\begin{tabular}{|c|c|c|}
\hline $\mathbf{S . N e}$ & Fermalatine cede & Dreg retrined in Dermis $\left(\mathrm{gtam}^{2}\right)$ \\
\hline $\mathbf{I}$ & F1 & $0 \_1$ \\
\hline 2 & $\mathbf{F 2}$ & 0.09 \\
\hline 3 & F3 & 0.05 \\
\hline 4 & F4 & 0.04 \\
\hline
\end{tabular}

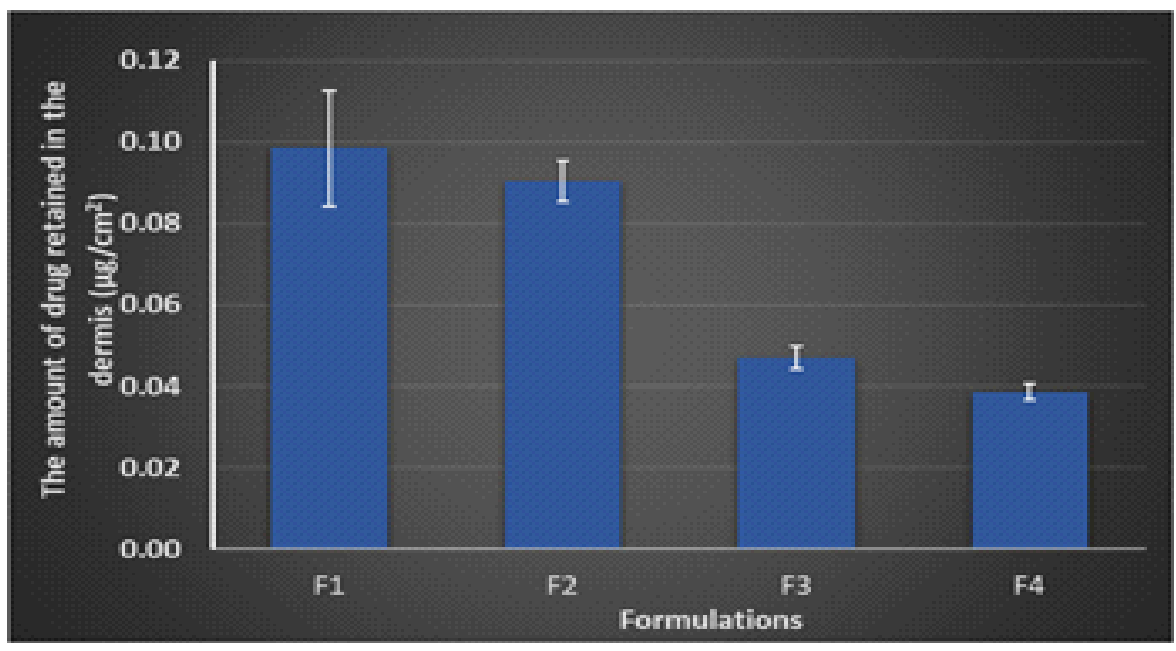

FIGURE 5: Shows the amount of retinol extracted from the active diffusion area of the dermis layer. The drug amount was represented in $\mu \mathrm{g} / \mathrm{cm}^{2}$ unit.

In Vitro Release Test (IVRT): In vitro release test was carried out in Franz Diffusion
Cell using PES (Polyether sulfone) synthetic membrane. 
Table 17: Shows the average amount of Retinol patch 1 release across the PES membrane into the receptor fluid

\begin{tabular}{|c|c|}
\hline Time point & Cumulative amount of drug in the receptor fluid $\left(\mu \mathrm{g} / \mathrm{cm}^{2}\right)$ \\
\hline 0 & $\mathbf{0}$ \\
\hline 0.71 & $\mathbf{0 . 3}$ \\
\hline 1 & $\mathbf{0 . 5}$ \\
\hline 1.41 & $\mathbf{E . 8}$ \\
\hline 1.73 & $\mathbf{0 . 9}$ \\
\hline 2 & $\mathbf{E . 9}$ \\
\hline 2.45 & $\mathbf{0 . 9}$ \\
\hline
\end{tabular}

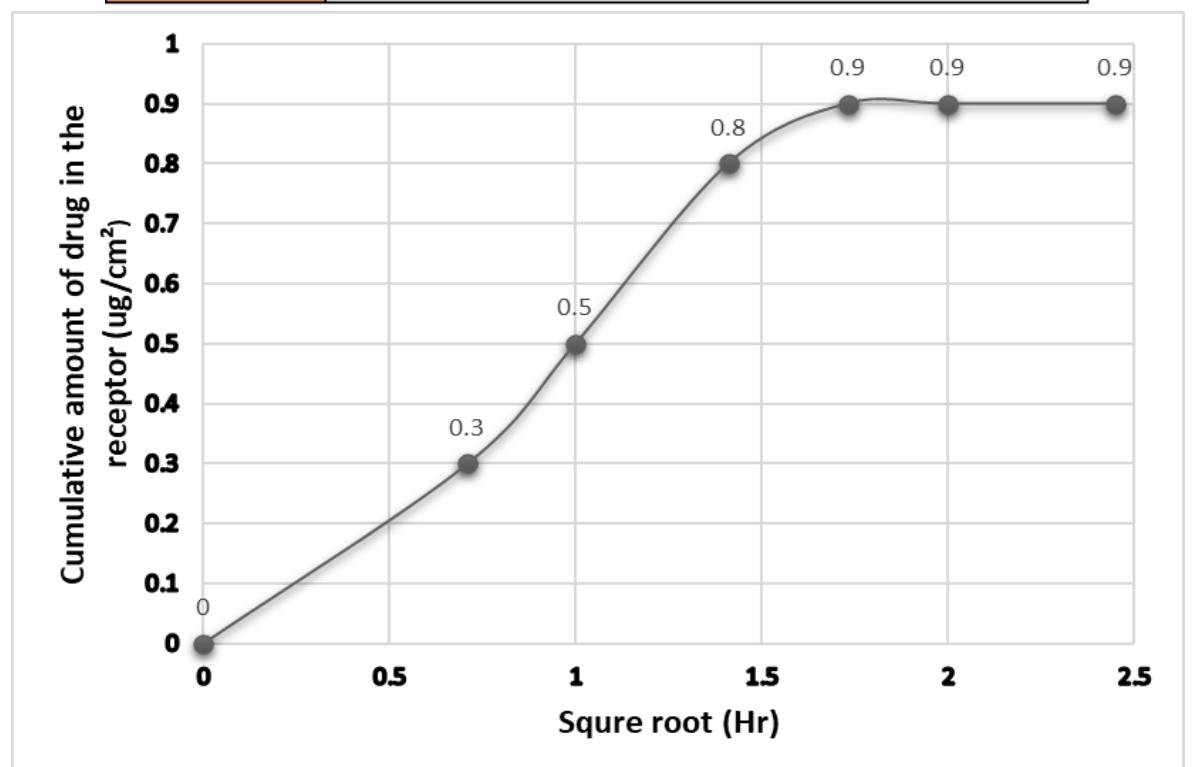

FIGURE 6: In Vitro Release Study in Retinol Patch 1

Table 18: Shows the average amount of Retinol patch 2 release across the PES membrane into the receptor fluid.

\begin{tabular}{|c|c|}
\hline Time point & Cumulative amount of drug in the receptor fluid $\left(\mu \mathrm{g} / \mathrm{cm}^{2}\right)$ \\
\hline 0 & $\mathbf{B}$ \\
\hline 0.71 & $\mathbf{E . 3}$ \\
\hline 1 & $\mathbf{E . 7}$ \\
\hline 1.41 & $\mathbf{1 . 1}$ \\
\hline 1.73 & $\mathbf{1 . 2}$ \\
\hline 2 & $\mathbf{1 . 2}$ \\
\hline 2.45 & $\mathbf{1 . 3}$ \\
\hline
\end{tabular}




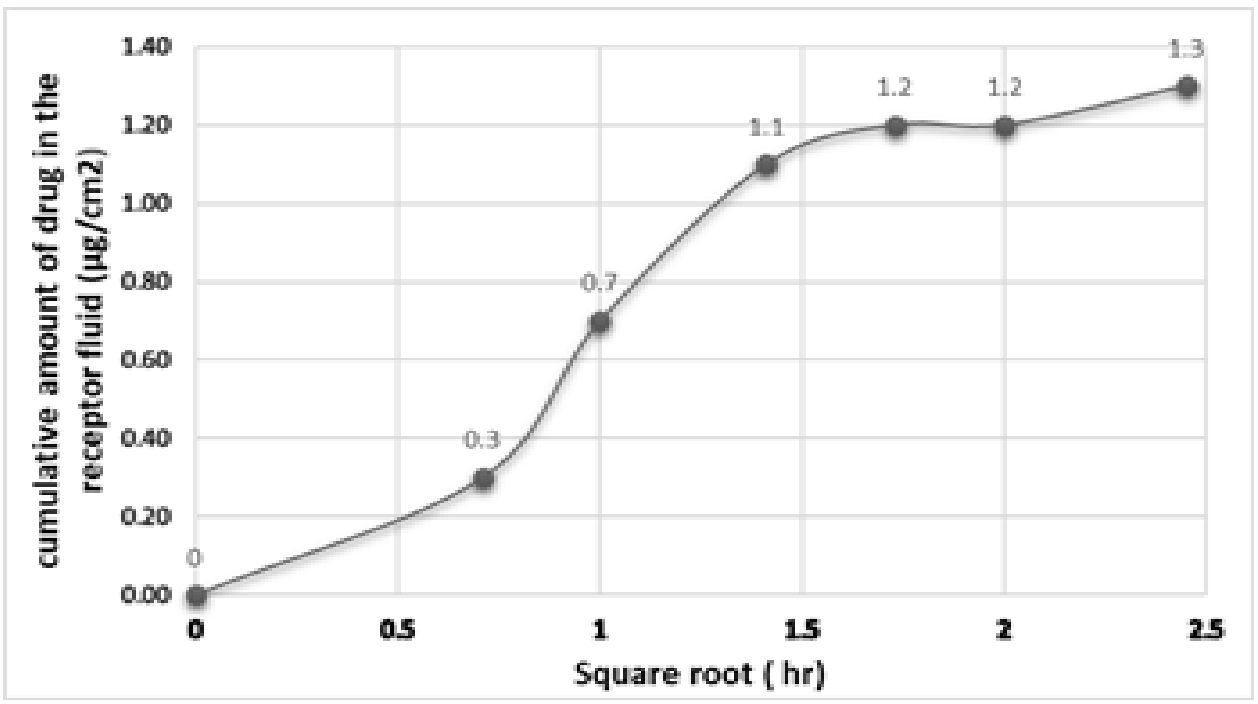

FIGURE 7: In Vitro Release Study in Retinol Patch 2

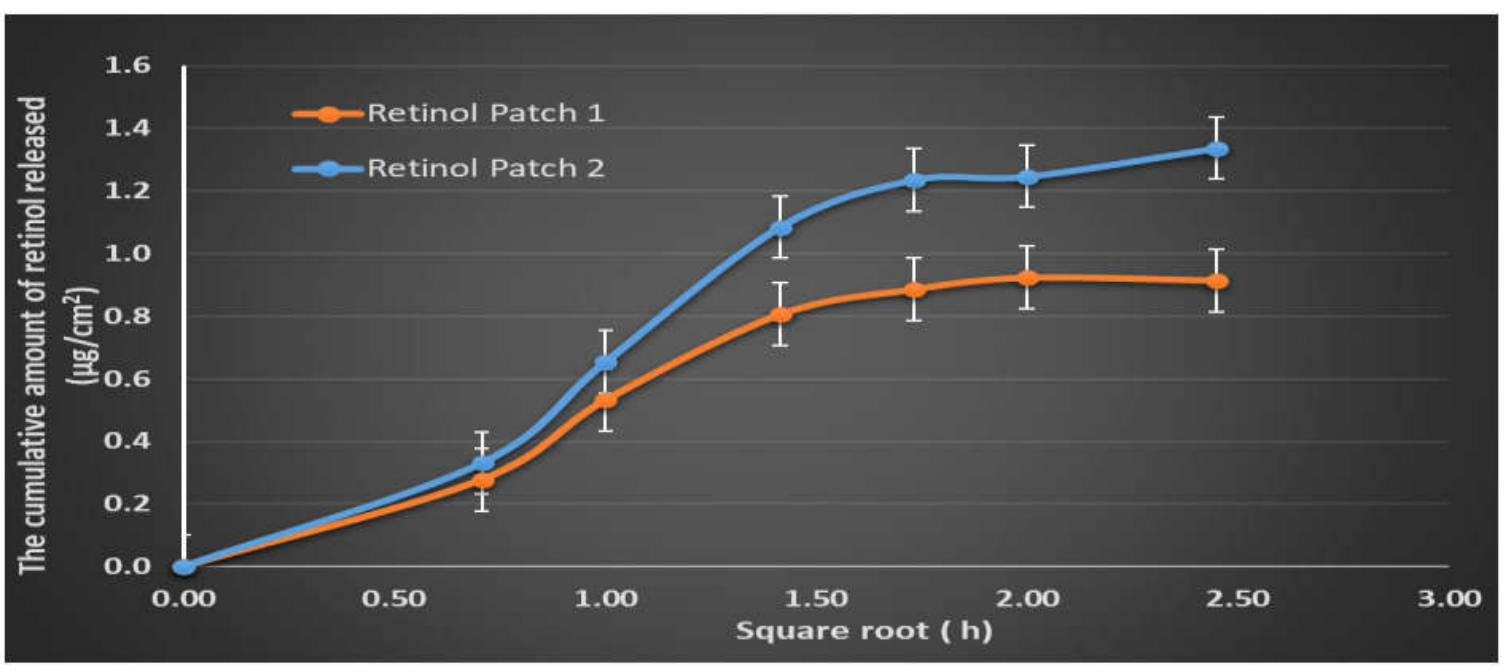

FIGURE8: Comparison of In-vitro release of Retinol patch $1 \&$ Retinol patch 2

DISCUSSION: The Invitro Permeation Study prepared patch carries out on human cadaver skin in 24 hours. From the IVPT study it was observed that, drug was not found in receptor fluid and the epidermis layer, drug are retained in all formulation data presented in table 15 and graph shown in figure 5. And some amount of drug in all formulation was retained in the dermis layer. Compared to all formulation, formulation $\mathrm{F} 1$ \& $\mathrm{F} 2$ is effective because in high amount of permeate through the epidermis and retained in dermis layer. And after IVPT result was found in Formulation1 and Formulation 2 high drug retained in dermis layer and formulation 3 or formulation 4 less amount of drug retained in dermis and study only formulation 1 and formulation 2 carried out in IVRT. In IVRT study was observed that, and the cumulative amount of drug in the receptor fluid $\left(\mathrm{ug} / \mathrm{cm}^{2}\right)$ data show retinol patch 1 (F1) the data presented in table 17 and graph show in figure 7 . \& retinol patch 2 (F2) the data presented in table 18 and graph show in figure 8. After this study, retinol patch 2 increase amount of drug release in the receptor fluid compare to retinol patch 1. The comparison graph of Invitro release of retinol patch 1 and retinol patch 2 show in the figure 9. 
CONCLUSION: Retinol was selected as the drug candidate for the development transdermal patch because of it is hydrophobic in nature, short half-life, and Retinoidsinhibit $\mathrm{MuV}$ in vitro due to upregulation of type I interferon (IFN) and IFN stimulated genes. The Laureth-4, Lauryl Lactate, Levulinic acid, Isopropyl myristate, Dimethyl sulfoxide and Oleic acid used as the permeation enhancer. The Laureth-4, Lauryl Lactate enhance permeability of retinol.

\section{REFERENCES:}

1. Mumps disease written by The Editors of Encyclopaedia Britannica. Alternative Title: epidemic parotitis.

2. Aili Cui, Zhen Zhu, Ying Hu, Xiuying Deng, Zhaodan Sun, Yan Zhang, Naiying Mao, Songtao $\mathrm{Xu}$, Xueqiang Fang, Hui Gao, Yuan Si, Yake Lei, Huanying Zheng, Jilan He, Hongwei Wu, Wenbo $\mathrm{Xu}$; Mum Epidemiology and Mumps Virus Genotypes Circulating in Mainland China during 2013-2015.

3. Kristi L. Koenig, MD Siri Shastry, MD Bandr Mzahim, MD Abdulmajeed Almadhyan, MD Michael J. Burns, MD Mumps Virus: Modification of the Identify-Isolate Inform Tool for Frontline Healthcare Providers.

4. Kaitlin J Soye, Claire Trottier, Thomas Z Di Lenardo, Katherine H Restori, Lee Reichman, Wilson H Miller Jr and Brian J Ward; In vitro inhibition of mumps virus by RetinoidsSoye et al. Virology Journal 2013, 10:337.

5. Windholeez $M$. The merk index, $9^{\text {th }}$ edition, merk \& co. inc, Rahway- 1976.

6. Mohammad Imani, Farzad Lahooti-Fard, Seyyed Mojtaba Taghizadeh, and Mitra Takrousta; Effect of Adhesive Layer Thickness and Drug Loading on Estradiol Crystallization in a Transdermal Drug Delivery System, AAPS Pharm SciTech, 2010, 11(3);1-9.

7. Farhat Mirza and Alka Lohani "Formulation and characterization of drug in adhesive transdermal patches of buflomedil hydrochloride School of
Pharmaceutical Sciences", IFTM University, Moradabad, Uttar Pradesh, India published 01 October 2015.

8. Mohammad Imani, Farzad Lahooti-Fard, Seyyed Mojtaba Taghizadeh, Mitra Takrousta1 Effect of Adhesive Layer Thickness and Drug Loading on Estradiol Crystallization in a Transdermal Drug Delivery System, AAPS Pharm SciTech, 2010, 11,(3), 1-8..

9. Sumit Chourasia, Tripti Shukla, Surendra Dangi, Neeraj Upmanyu, Nidhi Jain; "Formulation and evaluation of matrix transdermal patches of meloxicam" Journal of Drug Delivery \& Therapeutics. 2019; 9(1-s):209-213.

10. Mutalik, N, Udupa, Glibenclamide Transdermal Patches, Physicochemical, Pharmacodynamic and Pharmacokinetic Evaluations, Journal of Pharmaceutical Sciences, 2004, 93 (6), 15571594.

11. Sankar V, Johnson DB, Sivanand V, Ravichandran V, Raghuram S. Design, and evaluation of nifedipine transdermal patches. Indian J Pharm Sci 2003; 65:510-5.

12. "Prabhakar Prabhu, Samip Shah, Shankar Gundad", Formulation development and investigation of domperidone transdermal patches, International Journal of Pharmaceutical Investigation, 2011; 1(1), 1-6.

13. Sarfaraz MD*, Reddy Jayendra A, Hiremath Doddayya, Udupi R.H. "Trimetazidine Hydrochloride Transdermal Patch: Formulation and In-vitro Evaluation", article received on April 2012.

14. Samanta MK, Dube R, Suresh B, Transdermal drug delivery system of Haloperidol to overcome self-induce extrapyramidal syndrome drug dev Ind Pharm 2003;29(4):405-415

15. Vaibhav Rastogi, Pragya Yadav, Transdermal drug delivery system: An overview Department of Pharmaceutics, College of Pharmacy, IFTM University, Moradabad, Uttar Pradesh, India Asian Journal of Pharmaceutics. 2012, 1(5); 1-6. 